\title{
Natural Goodness, Rightness, and the Intersubjectivity of Reason: A Reply to Arroyo, Cummisky, Molan, and Bird-Pollan
}

\section{Citation}

Korsgaard, Christine. 2011. Natural goodness, rightness, and the intersubjectivity of reason: A reply to Arroyo, Cummisky, Molan, and Bird-Pollan. Metaphilosophy 42(4): 381-394.

\section{Published Version}

doi:10.1111/j.1467-9973.2011.01697.x

\section{Permanent link}

http://nrs.harvard.edu/urn-3:HUL.InstRepos:8822404

\section{Terms of Use}

This article was downloaded from Harvard University's DASH repository, and is made available under the terms and conditions applicable to Other Posted Material, as set forth at http:// nrs.harvard.edu/urn-3:HUL.InstRepos:dash.current.terms-of-use\#LAA

\section{Share Your Story}

The Harvard community has made this article openly available.

Please share how this access benefits you. Submit a story.

Accessibility 
Natural Goodness, Rightness, and the Intersubjectivity of Reason:

A Reply to Arroyo, Cummisky, Molan, and Bird-Pollan

Christine M. Korsgaard

I want to begin by thanking Christopher Arroyo, David Cummiskey, Lydia Moland, and Stefan Bird-Pollan for their interesting and provocative comments. There's more in these papers than I can possibly respond to in a reasonable space, so I'm just going to pick and choose. "The Origin of the Good and Our Animal Nature" spells out some of my current thinking on the good, so a summary of that paper will put me in a position to begin by addressing some of Arroyo's and Cummiskey's points. ${ }^{1}$

\section{1. "The Origin of the Good and Our Animal Nature" - a Summary}

We use the term "good" in two contexts: as a form of evaluation, and to denominate the final end of life and action - the summum bonum, or, in our case, the "human good." I start from the question what evaluative and final goodness have to do with each other. Do we use the same term because when we talk about "the human good" or "the good life" we are evaluating a life and its circumstances in general? If so, how do we go about doing that? Most things are evaluated with respect to their fitness to perform their function, but life and its circumstances do not have a function.

\footnotetext{
${ }^{1}$ The paper in question was one of three lectures I gave as the David Ross Boyd lectures at the University of Oklahoma in 2007 under the common title "Moral Animals," and which form the basis of the book on which I am currently at work.
} 
Korsgaard: Natural Goodness, Rightness, and the Intersubjectivity of Reason p. 2

I contrast three theories of the final good: an objective realist theory that identifies the final good with participation in intrinsically valuable activities; a hedonist theory that identifies the final good with pleasure or agreeable consciousness; and Aristotle's account, which identifies an entity's final good with its well-functioning as the kind of thing that it is. The first two theories suggest that evaluative goodness depends on final goodness; a thing is wellfunctioning when its functioning contributes to its final good. Aristotle's theory suggests an almost opposite relationship between evaluative and final goodness. It suggests that an entity is capable of a final good when it functions by being aware of its own evaluative goodness - that is, by being aware its own well- or ill-functioning, or, more strictly, of states that signal its well- or illfunctioning. This is because such an entity functions by developing evaluative attitudes - desire and aversion, pleasure and pain - towards things that affect its own functioning. Animals (including human animals) are entities that function by being aware of their own functioning. According to Aristotle's theory, then, it is the nature of an animal to have a final good, and final goods exist because there are animals.

Unlike some contemporary philosophers, I do not believe that this sort of "natural goodness," to use Philippa Foot's term, is inherently normative. ${ }^{2}$ But an account of normative goodness may be given by combining it with Kantian value theory. According to Kantian value theory, things that are good for their own sake are not characterized by a metaphysical property of intrinsic value -

\footnotetext{
2 Philippa Foot, Natural Goodness. Oxford: Oxford University Press, 2001.
} 
Korsgaard: Natural Goodness, Rightness, and the Intersubjectivity of Reason p. 3

rather, they are valuable because someone values them for their own sake, and because we reflectively endorse that value - that is to say, we legislate that value in accordance with the moral law. In the combined theory, final goods exist because there are animals. Good things are good because they contribute to or are partly constitutive of an animal's final good. And all of these goods are normative, when they are, because human beings reflectively endorse what is naturally good. This theory explains why value exists and what has it, while avoiding the metaphysical appeal to intrinsic values. Importantly, it also preserves an intuition that realist theories make it hard to explain - namely, that everything that is good is good because it is good for some valuing being, or some being who is capable of evaluative states - that is, for some person or animal.

2. The Relation Between the Natural Good and the Right: Reply to Arroyo Christopher Arroyo wonders whether the Aristotelian aspects of my thinking might push me towards a more realist account of the good. What he has in mind is not substantive realism in the form in which it was advanced by G. E. Moore, but the sort of realism associated with Aristotle's functional account of the good - the very sort of account I discuss in the paper I have just summarized. He also wonders whether my endorsement of that account of the good might push me towards an acceptance of the kind of moral theory indicated by Geach in his paper on "Good and Evil," in which the concept of a 
Korsgaard: Natural Goodness, Rightness, and the Intersubjectivity of Reason p. 4

good human act replaces talk of right and wrong. ${ }^{3}$ Geach says little in the paper in question about how we are to identify good human acts, but I think we may take it that the moral theory he had in mind was something along the lines that Philippa Foot has since developed in her book Natural Goodness. ${ }^{4}$ According to this theory, we can identify a good human life in the same way we can identify a good plant or animal life, by consideration of the way the organism functions; we can then identify virtues as properties needed to lead a good human life; and we can then identify good actions as those associated with the virtues in question.

Let me simply say how I stand with respect to all this. First of all, the notion of the good that I favor is the notion of a life that is good in the sense that it is good for the animal (possibly human animal) in question, not in the sense that it is morally good. However, in the paper summarized above, I do endorse the way that Aristotle connects the idea of a life that is good in this sense and a morally good life, and I will come back to that connection later. The Aristotelian notion of a good life that I develop is, as Geach would have it, a descriptive notion of the good, rooted in a conception of the way the animal functions. But as I mentioned earlier, I do not believe that this notion, all by itself, is a normative notion. I believe that the human good, in the descriptive

\footnotetext{
3 Peter Geach, "Good and Evil," Analysis, Volume 17, Number 2 (1956): pp. 33-42.

4 Cited above.
} 
Korsgaard: Natural Goodness, Rightness, and the Intersubjectivity of Reason p. 5

sense, only becomes a normative good when we confer value upon it through rational choice. ${ }^{5}$

Arroyo wonders what I mean when I say we "confer value" on things. Perhaps that way of describing my view was somewhat misleading, as if value were some sort of substance that our choices infuse into certain objects. Another way to put the point is to say that I think valuing is prior to value. Valuing is not a response to value, although it is a response to our natural good; rather, there are values because there are creatures who value things. To say that we confer value on things is to record that fact.

The reason I think that the human good becomes a normative good only when we confer value upon it is that I do not believe that normativity rests in a relation between a person and the good. I believe that normativity rests in the relations between people, including the relations between a person and herself. There is normativity when we make laws for ourselves and each other. The good does not make laws for people; people make laws for people. So our natural good has no claim on us, but we have a claim on ourselves, and on others, to choose in accordance with it. In The Sources of Normativity, I

${ }^{5}$ I also believe, incidentally, that we become committed to treating the good of the other animals as a normative good when we make that move. That is a conclusion I have argued for in my recent work on the treatment of non-human animals. See "Fellow Creatures: Kantian Ethics and Our Duties to Animals" available at http://www.tannerlectures.utah.edu/lectures/documents/volume25/korsgaard_2005. pdf

and "Interacting with Animals: A Kantian Account," forthcoming in The Oxford Handbook on Ethics and Animals, edited by Tom Beauchamp and R. G. Frey. Oxford: Oxford University Press, 2010. 
Korsgaard: Natural Goodness, Rightness, and the Intersubjectivity of Reason p. 6

discussed some other moral theories that involve the idea that something naturally good becomes normatively good when it is enacted into law by a rational being, or alternatively, when it is approved by the "moral sense." 6 The theories of Pufendorf, Shaftesbury, Hutcheson, Hume, and in my view Kant all exhibit this kind of conceptual structure. So an initial point is that I reject Geach's account because I don't think that the Aristotelian or functional or descriptive notion of the good gives us a sense of "good" that is normative all by itself.

The idea that normativity rests in the relations between people is of course also related to the difference between judgments of right and wrong and judgments of good and evil of the sort Geach favors. Assuming that Geach had something like Foot's theory in mind, I would say that the idea that someone in acting a certain way is exhibiting a vice, or even just that it is plainly a bad sort of action, does not by itself capture the sense in which his action can wrong another person. For that we need the thought that there are normative relations between the two people, not just a relation between the agent and the quality of his life or actions. Foot, in Natural Goodness, proposes to cover this problem by asserting that one of the facts about the way human beings function is this: "Humans establish rules of conduct and recognize rights."7 That's supposed to be a fact about the human form of life. Once it is in place that we "recognize rights," she apparently thinks we have the tools we need for explaining how you can wrong someone else. But this leaves everything to be said about why

\footnotetext{
${ }^{6}$ Korsgaard, The Sources of Normativity (Cambridge: Cambridge University Press, 1996).

7 Foot, Natural Goodness, cited above, p. 51.
} 
Korsgaard: Natural Goodness, Rightness, and the Intersubjectivity of Reason p. 7

human beings establish rules of conduct and recognize rights - and whether our reasons for recognizing rights are such that we must do so, or doing so is merely it a workable strategy for creatures of our kind. I think that we must recognize rights in order to be properly related to each other, and a theory of the Kantian type is needed to tell us why. That of course is just one case of a more general point. I do not believe that moral content can be derived from a theory of the virtues, or from a bare description of the way we in fact live.

However, in one way what I have just said is misleading. I do recognize a connection between the rightness of action and natural or functional goodness of the sort that Geach and Foot favor. But in my view, the rightness of an action does not rest simply in its constitutive contribution to the goodness of human life, as it does in Foot's view. Rather, as I argue in Self-Constitution, action itself has a more specific function, namely the constitution of agency or identity - and by extension, in the case of interaction with others, the constitution of shared agency. 8 So on my own view, an action that is right is right because it is good as an action, and good as an action because it successfully realizes the function of action: the constitution or unification of the agency and identity of the person who acts.

Now let me return to the connection between a good life in the sense of a life that is good for a creature and in the sense that the life is morally good. I

8 Korsgaard, Self-Constitution (Oxford: Oxford University Press, 2009). Since this is the pervasive theme of the book, it's a little hard to identify specific locations, but see for instance, §1.2.1-1.2.2 (pp. 8-9) and §1.4.1-1.4.2 (pp. 18-19); §5.1 (pp. 81-4); and for shared action, §9.3-9.7 (pp. 184-206). 
Korsgaard: Natural Goodness, Rightness, and the Intersubjectivity of Reason p. 8

said before that Aristotle's theory of the good is in the first instance a theory of what sort of life is good-for a certain sort of creature. It is not, in the first instance, a theory of the good life in the sense of a morally good life. In "The Origin of the Good and Our Animal Nature," however, I do argue in favor of Aristotle's view that there is a conceptual connection between a life that is good for a human being and a good human life in the moral sense. More specifically, I argue that if Aristotle is correct in thinking both that moral virtue is essential to human well-functioning and that the final good is to be a well-functioning member of your kind, then it will fall out as a kind of necessary truth that virtue is necessary (but not sufficient) for the achievement of the human good.

But this is still not an endorsement of the Geach/Foot style of ethical theorizing. Geach and Foot, or at least Foot, seem to think that you can simply read a theory of the moral virtues off of a description of the way human beings in fact live and function. Justice is a virtue in human beings because human beings "establish rules of conduct and recognize rights." Aristotle himself, however, does not proceed like this. While Aristotle did think that virtues in the strict sense are properties that enable a thing to perform its function well -

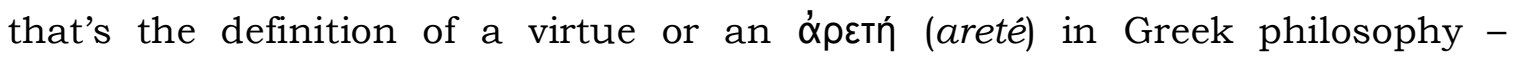
Aristotle thought that some philosophical work is required to show that the properties that we ordinarily call "the moral virtues" are virtues in this strict sense. For him, the human function is not just "living our sort of life." It is living our sort of life characterized in a particular way, namely as a life governed by practical reasoning. And the argument of the Nicomachean Ethics is supposed to show us how the properties that we ordinarily call "the moral 
Korsgaard: Natural Goodness, Rightness, and the Intersubjectivity of Reason p. 9

virtues" make us good at leading a life governed by practical reason - how they make us good at rational choice. ${ }^{9}$ That is a way of showing that they really are virtues, in the strict sense. That element is entirely lacking from the Geach/Foot strategy for identifying good and bad actions. And without it, I think their account of what counts as a good or bad action is simply assertion.

3. Kantianism vs. Consequentialism: Reply to Cummiskey

David Cummiskey wonders why a Kantian cannot be a consequentialist. Geach and Foot's style of argument was originally addressed against consequentialism: they argued that we could give no clear sense to the idea of a good state of affairs. This is because - although Geach and Foot do not quite put it this way - a state of affairs does not have a function. I begin my argument in "The Origin of the Good and Our Animal Nature" with a similar worry, namely about whether the idea of a good life makes any sense, given that it is not clear that life has a function. But I do in the end come down in favor of the idea that we can formulate a conception of the good life, a descriptive conception, and I also argued above that we confer normative value on this sort of life when we choose our own good. So our lives can be good not only in the sense of being good for us, but also in the sense that our good is something we deem worthy of choice - a good life is normatively good. Why then shouldn't we try to maximize this good? For several reasons.

${ }^{9}$ I defend in this conception of what is going on in the Nicomachean Ethics in a pair of papers in The Constitution of Agency (Oxford: Oxford University Press, 2008), "Aristotle's Function Argument" and "Aristotle on Function and Virtue," pp. 129-73. 
Korsgaard: Natural Goodness, Rightness, and the Intersubjectivity of Reason p. 10

In the first place, I don't think the idea of maximizing the good - that is, of adding goods across the boundaries between persons, or between persons and the other animals - makes any clear sense. Since I believe that the good is essentially relational, I believe that everything that is good must be good in virtue of being good for someone - for some person or some animal. And a mere aggregation of, say, my goods with David's and Lydia's and Stefan's and Christopher's is not obviously good for anyone, because we do not constitute an aggregate person for whom this aggregate thing is a good. Aggregating goods across the boundaries between persons is not really an intelligible way of "doing the most good."

Now of course it is often objected when people make arguments of this kind that we have some intuitions in favor of aggregation, and we need to explain them. That's a subject I've been thinking about lately, ${ }^{10}$ so let me now modify the stark claim I just made. I think that there are some cases in which we can perhaps make sense of the idea of "doing more good" in a way that is consistent with the thesis that everything that is good must be good for someone. The obvious case is when we can add more goodness-for-someone without subtracting from anyone else's good. If I am choosing between confering a benefit on David alone or an equivalent benefit on both David and Stefan, perhaps I do "more good" by conferring the benefit on both of them. That is good for David and good for Stefan, and that is doing more good than

10 I consider aggregation in the course of arguing against that feature of Peter Singer's account of our duties to animals in "Interacting with Animals: A Kantian Account," cited above. 
Korsgaard: Natural Goodness, Rightness, and the Intersubjectivity of Reason p. 11

just doing good for one of them. And, although I admit I have more doubts about this, I think we can perhaps make the same argument about the choice between conferring a benefit on Lydia and conferring the same sort of benefit on both David and Stefan, provided no one has any prior claim on the benefit. But certainly no such argument can be made about taking the benefit away from Lydia to give it to David and Stefan. That may be better for David and for Stefan, but it is worse for Lydia, and that is all there is to say. There is no aggregate third entity for whom this is better. A second way in which it might make sense to say we do more good is this: again, if there is no prior claim on a resource, it might be said that we do more good if we give it to the party to whom it does the most good. We give the painkiller to the one who is suffering the most, for example. It perhaps makes sense to say that we do more good that way. But it is essential to this argument that there is no prior claim on the resource being distributed. If Christopher has a claim on the painkiller and I take it away from him to give it to David, that is better for David but worse for Christopher. Again, there is no aggregate third entity for whom this is better. ${ }^{11}$ Roughly speaking, if everything that is good must be good for someone, we can add goods by giving goods to more people, but we cannot add goods by taking things away from some people and giving them to others, since that is worse for the ones from whom things are taken away. So I believe that maximization, the idea of which requires balancing some people's goods or interests against other

11 And if there were an aggregate third entity, the fact that it would be better for this third entity would only come into conflict with the fact that it would be worse for Christopher: nothing would be settled. See Self-Constitution, §3.3.4, pp. 56-7. 
Korsgaard: Natural Goodness, Rightness, and the Intersubjectivity of Reason p. 12

people's goods or interests, is ruled out on conceptual grounds. It is inconsistent with the thesis that everything that is good is good for someone.

So contrary to what Cummiskey says, I don't think that the only problem with utilitarianism is its acceptance of the view that action is production. I also think it operates with a conceptually flawed conception of the good, that makes the good seem addable in ways that it is not. Nor do I think that the dispute between consequentialism and deontology is exactly a dispute about the nature of moral reasons. I think it runs deeper than that.

There are many ways in which people have characterized the essential difference between consequentialist and "deontological" approaches to ethics. Often these characterizations proceed from the consequentialist point of view. For example, people sometimes say that consequentialists think it is always right to do what maximizes the good, while Kantians and other deontologists think (perversely, it is implied) that sometimes we should not do that, because there are "side-constraints" on the promotion of the good. Less polemically, people sometimes say that deontologists think that some actions are intrinsically right, apart from their consequences, and that this kind of value has priority over the good. But there is another way of thinking of the difference between these two kinds of theories that I think is deeper and goes more to the heart of the matter. This way of thinking about the difference is made available when we reflect on the implications of Kant's principle that we should treat human beings as ends in themselves.

I think that when we think about this formula we can see that consequentialists and Kantians have different views about what the subject 
Korsgaard: Natural Goodness, Rightness, and the Intersubjectivity of Reason p. 13

matter of ethics is. This is related to the conception of action as production: consequentialists take the subject matter of ethics to be the results produced by our actions, and take the main questions of ethics to be things like: "What results should we aim to bring about? What should we make happen? How can we make the world the best possible place?" Kantians on the other hand take the subject matter of ethics to be the quality of our relationships and interactions, both with ourselves and with each other. So Kantians take the main questions of ethics to be things like "how should I treat this person? What do I owe to him, and to myself, in this matter? How can I relate to him properly? What should our interactions be like?"

Of course I am not saying that either view ignores the other view's main questions. But the order of dependence is different. It is a notorious fact, much discussed in the critical literature, that consequentialists try to derive the values that concern the quality of our relationships from considerations about what does the most good. If you should be just and honest and upright in your dealings with others, according to the consequentialist, that is because that is what does the most good. If you are allowed to be partial to your own friends and family, and not required always to measure their interests against the good of the whole, that is because it turns out, the consequentialist claims, that people maximize the good of the whole more efficiently by attending to the welfare of their own friends and family. It is less often noticed, but just as true, that in a Kantian theory, the value of producing the good is derived from considerations about the quality of our relationships. The reason that pursuing the good of others is a duty at all in Kant's theory is that it is a mark of respect 
Korsgaard: Natural Goodness, Rightness, and the Intersubjectivity of Reason p. 14

for the humanity of another that you help him out when he is in need, and more generally that you help him to promote his own chosen ends when you are in a position to do that. This is why it is a serious mistake to characterize Kantian deontology as accepting a "side-constraint" on the promotion of the good. Kant does not believe there is some general duty to maximize or even promote the good that is then limited by certain deontological restrictions. Rather, he believes that promoting the good of another, and treating her justly and honestly, are two aspects of respecting her as an end in herself.

In Self-Constitution, I argue that morality must be grounded in formal principles - principles that prescribe that we deliberate in certain ways in general, like the categorical imperative - rather than in substantive principles that is, principles recognized as distinctively "moral" by their content. ${ }^{2}$ And I argue that the principle of utility is a substantive principle. ${ }^{13}$ Cummiskey sometimes describes me as "rejecting substantive principles," but that may be a misleading way to put it - my point is that substantive principles must be derived from formal ones. But as Cummiskey points out, that leaves it open whether we might derive the substantive principle of utility from the categorical imperative test. He says:

Indeed, Kant thought that our own perfection and the happiness of others were just such ends [that is, morally necessary ends], and so the argument thus far does not rule out, in principle, that

12 Korsgaard, Self-Constitution. See §3.1-3.2 (pp. 45-52) for the distinction, and $\S 4.2$ (pp. 64-7) for the argument.

13 Self-Constitution, §3.3 (pp. 52-58). 
Korsgaard: Natural Goodness, Rightness, and the Intersubjectivity of Reason p. 15

there are necessary ends that we should promote as effectively as possible. Of course, Kant also thought that these ends are captured by imperfect duties that are limited by perfect duties, but this is exactly what needs to be shown and not just assumed.

I feel like saying, "So who's just assuming it?" The arguments here are old and familiar. Utilitarianism in principle allows that the good of some, possibly even the lives of some, may be sacrificed for the sake of others on the grounds - the intelligibility of which I have already challenged - that this does more good overall. Even if aggregation were intelligible, it would allow that people should be treated as mere means. That is contrary to perfect duty in the most general sense. And this shows up in all kinds of particular ways. In principle, consequentialism allows you to break promises, commit injustices, violate rights, enslave the helpless and so forth, if it does enough good. Even if it made conceptual sense, we could not will the principle of utility as a universal law because we would have to reject it in cases where these were the results. Insisting that these cases are not really likely to come up, as utilitarians are wont to do, is nothing to the purpose. The universalizability test does not require that the case that forces us to reject the principle's standing as a universal law be likely to come up. It only requires that there be such cases.

Cummiskey is of course right in thinking that I would reject the distinction between the outcomes of decision procedures, on the one hand, and standards of rightness, on the other, on which many defenses of utilitarianism ride. I am what in Sources I called a procedural realist and what has now come to be called a constructivist. According to constructivism, as I understand it, a 
Korsgaard: Natural Goodness, Rightness, and the Intersubjectivity of Reason p. 16

normative concept exists not to describe normative entities or facts, but to mark out the space for the solution to some human problem. We face a problem, the problem of deciding what to do, and the concept of the right is the concept of whatever solves that problem. ${ }^{14}$ The idea of a standard of rightness that is literally independent of a decision procedure seems like exactly the sort of realist metaphysics about value that a Kantian should reject.

It is a different point that the standard that is given by the procedure is not always most effectively met by actually carrying out the procedure. Often it is needless because we already know the answer. Sometimes there is no time. I suppose these are the sorts of cases Cummiskey has in mind when he urges that the categorical imperative procedure would yield the conclusion that agents should not always deliberate in accordance with the categorical imperative procedure. Cummiskey also urges the case of a demon who threatens to destroy humanity unless we all take a drug that causes us to reason in accordance with substantive principles that in fact are consistent with the dignity of humanity, although (I take it this is what he means) the principles do not explicitly refer to the dignity of humanity, and we do not think about what we owe to that dignity when we apply them. Cummiskey thinks the question whether we should take the drug is open and interesting. I think that the question is pretty much equivalent to the question whether we should agree to be slaves if our masters promised that they would never make us do anything wrong, and if the only alternative were the destruction of humanity.

\footnotetext{
${ }^{14}$ See my "Realism and Constructivism in 20th Century Moral Philosophy" in The Constitution of Agency, cited above.
} 
Korsgaard: Natural Goodness, Rightness, and the Intersubjectivity of Reason p. 17

Perhaps the good Kantian answer is that if we are faced with the destruction of our capacity to think for ourselves and choose in the light of our own reflection, then our humanity will be destroyed either way. So we should say "no" to the demon - for at least that way we will not have destroyed our humanity ourselves.

4. Practical Identity and the Intersubjectivity of Reason: Reply to Moland and Bird-Pollan

Lydia Moland and Stefan Bird-Pollan in various ways urge the virtues of Hegel against or as a supplement to my account. Moland urges that I am forced to accept the Kantian view that the free and identity-unencumbered self who chooses to endorse our practical identies is the "real" self, while the self that actually has the practical identities - the self that is bound by our ordinary commitments - is not the real self. Let me first clear up one matter. Moland claims that Kant's own view is that whenever we act on desires generated by our commitments in the external world we do not act freely. That is not Kant's view as I understand it. Kant's view is that we act freely so long as we determine that a maxim of acting on the commitment in question could serve as a universal law. Permissible action undertaken as such, in other words, is not unfree on Kant's view. But Kant's view as it stands makes it hard to understand why we would act on our desires, even when it is permissible, because it makes it hard to understand why we identify with them at all. They seem just to be phenomena caused in us by the external forces of nature. The idea of practical 
Korsgaard: Natural Goodness, Rightness, and the Intersubjectivity of Reason p. 18

identity is in part supposed to remedy this problem: we identify with our desires because they spring from our practical identities.

In $\$ 2.4 .2$ of Self-Constitution, I argue that we do not have to choose between identifying with the supposedly empty "free" self and the self that is the subject of our particular identities or commitments. Self-constitution is an ongoing process, in which what the self does is endorse and so identify with our specific practical identities. Such commitment reoccurs whenever I choose to do what my practical identity requires, or to avoid what it forbids. If what my free self does is identify with my specific practical identities, and I in turn identify with my free self, how am I failing to identify with my specific practical identities? It endorses my practical identities, so if I identify with it, I endorse them too. Once we recognize that engaging in this process of self-constitution is what it means to have an identity, we are not faced with a choice between identifying with the free self and identifying with our particular commitments. To put the point another way, commitment itself is an activity of the self, not a state - not even a state that results from an activity of the self. Being committed is like living - it is something that we do.

To put it in a less formal way, there are two points that I take to be important here. The first is that active ongoing endorsement of my everyday commitments is a deeper way of identifying with them than simply taking them for granted or as given. Constant, active re-endorsement of your commitments is not a way of distancing yourself from them. Of course - and this is the second point - I may have to set aside the claims of some particular form of practical identity or commitment when morality requires it. But that does not 
Korsgaard: Natural Goodness, Rightness, and the Intersubjectivity of Reason p. 19

show that I identify with my free self rather than with my own practical identity. When I act morally, I act from my identity as a human being, bound by the rules of our common humanity, and that is as much a form of practical identification as any other.

Citing my view that we endorse our contingent practical identities because we need reasons, Moland argues that "What commitments they are is in the end secondary so long as they provide us with reasons to act one way rather than another." She argues that we do not experience our commitments in this way. I think that there is an element of contingency in our particular commitments, and that we can recognize this without taking them less seriously. We are who we are, and love who we love, in large part because of where we landed, and we know that, but if we actively endorse our commitments in the way I described above, that does not make them less significant. The attitude I think we should have is the one I describe at the end of Self-Constitution. 15 Each of us is a person, but the only way to be a person is to be a particular person. Our commitments are important, but they are not the only ones we might have had: others are just as important. So we should each of us regard our particular life as one realization of human possibility, as one possible realization of human value.

Moland also thinks that I portray all commitments "as equal, and therefore equally easy to abandon." I don't know what gave rise to this impression, but in any case that is certainly not my view. Of course some of

15 Self-Constitution, cited above, §10.1, pp. 207-12. 
Korsgaard: Natural Goodness, Rightness, and the Intersubjectivity of Reason p. 20

our practical identities are more central and important than others - ordinarily, for instance, one's friendships and one's career are more central than being a supporter of a certain team. And, as I certainly do make clear, I think some of our practical identities are re-enforced by our moral commitments, either because they bring moral responsibilities in their wake - like having children, or accepting a position - or because there is a moral as well as a personal foundation for them - as in the case of gratitude towards parents and other supportive people.

Moland advocates Hegel's theory of how we become free, which is through the recognition of others. As she describes the theory, we start as agents who are self-determining only in the sense that we can follow our own desires, but we learn to evaluate our desires and sometimes curb them when we recognize another person's claims to self-determination. Here I take it that her argument has a common theme with that of Stefan Bird-Pollan, who argues we must find a way to make the step from "weak" to "strong" autonomy. Both, if I understand them correctly, think that what I call the publicity or intersubjectivity of reason must be developed through actual interaction with concrete others, whose claims we recognize. Bird-Pollan suggests, although this was not in Moland's account, that this is in part because our imperfect rationality requires, at the beginning, the reinforcement of external sanctions.

But I do not see how we can recognize the claims of others unless reasons are already, or rather essentially, public or intersubjective. If I am simply a being who follows my desires, the desires of others will be nothing to me unless I happen to desire that their desires should be satisfied. If we were 
Korsgaard: Natural Goodness, Rightness, and the Intersubjectivity of Reason p. 21

weakly autonomous, we could not recognize the desires of others as having a claim on us, because we could not recognize in others what we do not find in ourselves. A being that acts only on its immediate desires does not recognize the idea of a claim. Our ability to acknowledge the claims of others is essentially tied to our ability to make claims on ourselves: there is no intelligible route from wantonness to autonomy through the claims of others.

Of course, as a matter of moral development, our interactions with others whom we love helps us to make a start at seeing the force of the reasons of others. ${ }^{16}$ We must learn to acknowledge the reality of others, to put it in Nagelian terms, and that is easiest (in some ways) with the near and dear.17 But as a matter of metaphysics, I think that our encounter with the publicity of reason is more intimate than that. In Chapter 9 of Self-Constitution I argue that reasons must be public in their normative force in order to bring unity to the self. That argument is too elaborate to repeat here, but the idea is that unless I recognize the normative force of the claims of both my present and future selves, I cannot hold my own agency together over time well enough to interact properly with others. And the claims of my present and future self are certainly distinct from the desires I have now, so that kind of self-unification requires more than what Bird-Pollan calls "weak autonomy." Even the decisions you

\footnotetext{
16 It is also true that, developmentally, our parents and caretakers help us learn the kind of self-control that is associated with instrumental reasons and reasons of prudence. But that does not show that those reasons are constituted by our relations with those actual others.

17 Thomas Nagel, The Possibility of Altruism. Princeton: Princeton University Press, 1970.
} 
Korsgaard: Natural Goodness, Rightness, and the Intersubjectivity of Reason p. 22

make for yourself alone have to take the form of laws. When you decide to take the means to an end, you are deciding to take those means even if you should find it difficult or painful in certain ways that might make you reluctant to take them. Of course some sources of reluctance are good reasons for changing your mind - we do not continue to pursue an end at any cost. But if any source of reluctance whatever was a good reason for changing your mind, there would be no content to your original commitment to taking the means: you would only be committing yourself to doing whatever you felt like doing anyway.18 So whenever we act for reasons, we make claims even on ourselves: claims whose normative force is public, in the sense that they reach out from one moment or aspect of the self to another. That is what enables us to recognize the claims of others: that we see our own condition reflected in them.

That actual norms in their detail are hammered out communally, as Bird-Pollan urges, and that political institutions shape and limit our efforts at self-constitution, as Moland urges, are both points that I am happy to take on board, but I do not think these facts have any deep metaphysical implications about the foundation of morality. In my view, Hegel's view on this matter is one source of the overly politicized conception of morality that has characterized the "continental" tradition in philosophy, which barely distinguishes moral theory from social thought more generally. Of course the "analytic" tradition has its own variant of the over-politicized conception of morality, enshrined in the commonly stated view that morality is primarily about the "other-directed." In

18 See Self-Constitution, $§ 4.5$ (pp. 76-80), for one version of this argument. 
Korsgaard: Natural Goodness, Rightness, and the Intersubjectivity of Reason p. 23

either of its variants, I believe that an overly politicized conception of morality takes us too far away from an insight that I think of as common to Plato, Aristotle, and Kant: that our capacity for treating others rightly, and relating to them well in general, is in part the outward expression of an integrity that must be achieved inwardly by the self. 